\title{
Supplementary Journeys
}

\section{Author(s): F. C. Quicke}

Source: The Geographical Journal, Vol. 17, No. 2 (Feb., 1901), pp. 129-133

Published by: geographicalj

Stable URL: http://www.jstor.org/stable/1775534

Accessed: 27-06-2016 09:11 UTC

\section{Your use of the JSTOR archive indicates your acceptance of the Terms \& Conditions of Use, available at}

http://about.jstor.org/terms

JSTOR is a not-for-profit service that helps scholars, researchers, and students discover, use, and build upon a wide range of content in a trusted digital archive. We use information technology and tools to increase productivity and facilitate new forms of scholarship. For more information about JSTOR, please contact support@jstor.org.

The Royal Geographical Society (with the Institute of British Geographers), Wiley are collaborating with JSTOR to digitize, preserve and extend access to The Geographical Journal 
steamer, which left for Fashoda on May 8. Thus for three months I had to amuse myself as best I could. The country is flat, was inundated and uninteresting, while the mosquitoes were indescribable, and even the great kindness I received from Mr. Engh, the commandant of Lado, and his brother officers, did not compensate me for the trying inactivity of those three months.

Bimbashi Sanders, Governor of Fashoda, took me off in the Kaibar on August 7, and a month later I was in England. Not having received letters for fifteen months I was at times anxious about my two colleagues. Now I found they had done splendidly, having not only accomplished the work I had allotted them and reached their respective coasts in safety, but each had found his way to the seat of war, while Captain Alexander has been through the Ashanti war, and Mr. Weller had been to the West Coast and back since we parted. I have only one thing more to say, and I say it in proof of my opinion that there has been a great deal too much killing in Africa. During the last ten years my routes, added to those of my colleagues, exceed 20,000 miles beyond the reach of railroads, and mainly in the most remote parts of Africa of to-day, yet no one of us has found it necessary to take a single human life, and for my own part I would have no compunction in travelling again unarmed over any part of those 20,000 miles.

\section{SUPPLEMENTARY JOURNEYS.}

By Captain F. C. QUICKE.

After Major Gibbons and Captain Hamilton had started on their respective journeys from Sesheke in March, 1899, with the kind help of Lewanika, who, owing to the floods, was at Mafula, a station at the edge of the plain, I reached the Nengo confluence of the Zambezi.

Leaving the Nengo, I followed the Luwe through a very pretty valley to its source. 'The natives here were very busy preparing rubber and making bark-cloth blankets. After passing through the hilly country and crossing the Chikolui and Kuti rivers, I arrived towards the end of May at the Kwando-Kubangwi confluence, where Major Gibbons had proposed we should meet. There was much sickness amongst the inhabitants here.

After a delay of twelve days of general unhappiness, I continued my journey up the Kwando to its source. Leaving the Kwando, I found great difficulty in getting my Marotse to travel any further from home. My path to the Lungwebungu lay over close billy country some 5000 feet above the sea. There is practically no bird or animal life, the wandering Vachibokwe having long ago killed off anything that 
might have existed. They are said to pursue to its extermination even the mouse, so highly do they prize meat. I found the Lungwebungu a great river, and very navigable, winding through an inundated plain 2 to 3 miles wide. The Valuchasi, who inhabited the upper reaches, were very homely. I used to enjoy their singing when gathered together in their villages before dispersing to their work at dawn.

Following the course of the river down to the Zambezi, I had a few days' good sport in the marshes after Lechwe. My headmen and followers behind me were put to flight by a snake-native name "Deruye," a black snake some 6 feet long, of the cobra type, that sat up and disputed our path until I had secured a spear. On another occasion I have been marvellously surprised by its wonderful vitality and strength. I cannot recommend any previous part of my journey to one of sporting proclivities. The country is hardly populated enough for missionary enterprise. The trader in rubber may succeed in future Jears if the rubber root still exists. Briefly, the main characteristics of the country may be thus described: Undulations, for the most part of white sand covered with forest, trees with very little foliage, no undergrowth, and intersected by rivers of clear water winding through flat alluvial valleys. These undulations rise in altitude and steepness as one travels west, until they may almost be described as hills.

On arrival at Lialui I found Major Gibbons full of fresh plans, forced on him through the conduct of his people.

On September 2 I bade farewell to my colleagues and to Major Coryndon, to whom, apart from his services to the expedition, I am personally grateful for many acts of kindness. First I followed the eastern Luena to its source, from some 20 miles east of its confluence with the Zambezi. I found the river larger than I expected from what I had seen of it near the Zambezi, which it enters in four separate streams. This journey was much pleasanter than my previous one. The Mankoya, untainted by intercourse with the Ovimbundu, are hospitabie; like most tribes, they have their special little customs and characteristics. The women of this tribe had a most peculiar cry of greeting-I thought at first it was a cry of terror. The country is picturesque though dried up, bush fires having passed through the woods, charring the trunks and eating up the grass; dark firm soil giving place to the sand I encountered on my journey west. Game is to be found, and lions at one place were preying on the natives, who protect their villages with stockades. Above the Luompa confluence the chief Motondo, with his following and a large band of drums, received me in great state, and sat for hours, for these chiefs never take a hint to go. In his village, the variety of charms amused me, chief preference being given to an old elastic-side boot.

As we passed through the Bamashasha country it became flatter, the trees in the forest standing further apart, but absolutely shadeless. Here 
game was very plentiful. Wildebeest and zebra in great quantities would graze in the river valley. After a worrying time with my carriers, I descended towards the Loenge, leaving the constant wind which always blows on the higher land behind me. In about $15^{\circ} \mathrm{S}$. lat. I struck the Loenge-a fine picturesque river over a quarter of a mile wide, with slight rapids every 10 miles or so, and numerous islands. I found hartebeest, pallah, waterbuck, pookoo, the lesser reedbuck, bushbuck, and a small gazelle, of which I saw some twenty in one herd, but failed to-secure a specimen. I enjoyed my journey up the Loenge immensely, in spite of the constant trouble my porters gave me; for two days they had their loads carried for them, and were driven along by twenty natives lent me by a friendly Mankoya chief. I reduced the chance of night desertion by collecting their bows, arrows, and spears, and later, when I entered Kawandi country, I was somewhat assisted through their fears of the Wakawandi, who often would follow us at a distance. The Lufupa, which I followed to near its source, was smaller, but very similar to the Luena river, i.e. a swift stream flowing between narrow banks among the hills, drying up entirely at places at this time of the year on entering the flatter valley. Where I left the Lufupa, I was treated in a friendly way by one Rundumina, who ruled over a cluster of villages, and owed allegiance to Lewanika. The people flocked in all day, and hearing I was fond of eggs, many aged and rotten ones were brought me. The country is high, and teams with white ants, bees, tsetse, horse, and other flies. The noise some nights was not caused by their moving to and fro, but by myriads of white ants simultaneously pecking at the dried leaves, etc., under cover of my round-sheet, making a sound similar to the scratching of a rat. These ants, as is well known, will not feed, except when hidden by something to protect them.

Journeying west, I crossed the Kabompo at its junction with the Mumbeshi. Proceeding up the right bank of the former river, I stopped at a cluster of Mambunda villages, their chief named "Muyanga." I joined him in a pleasant two-day hunting expedition, though one night we were all driven from our fires and brushwood shelters into the rain by the red army ants. These red ants have caused me more uncomfortable nights than anything else. A warm feeling over the arms and head is usually the first awakening; then a simultaneous attack over every part of the body necessitates a hurried flight and removal of every stitch of clothing.

After a twelve-day delay, during which I failed to get either a relay of porters or any information out of the natives, I started off with my Bamashasha in a north-west direction into country inhabited by the Valunda, a wretched, timid race. Then I reached a village, the chief of which, " Kaata," had Mambari visitors trading for rubber. They had come from Nyakatoro, and willingly gave me information, which 
did not please my Marotse, who wished to go straight to Nyakatoro. They interrupted me, and were insolent. The Zambezi boy, my personal servant, seized my rifle; on looking round, after depriving him of it, I witnessed the funniest of sights : Kaata and his followers fleeing to their village, his stcol upset, his gift of eggs broken, and the manioc flour strewn over the ground; my Bamashasha's backs disappearing in the bush; the Marotse hysterical, and my two Mambari friends calmly seated on their stools. Peace restored, guides were provided for a short way.

Crossing the Lunga one evening, which is a Kabompo affluent, but, nevertheless, a larger river, I noticed for the first time many fireflies, or beetles, giving the same light. I could gather no information, for there were but fow inhabitants, and these we could not catch. Owing: to the hills, the rains, and lack of food, my carriers became weak and knocked up, and, with the connivance of my Marotse, deserted one night. It was useless trying to go on, so, tired of being a slave-driver, I watched my Marotse pack up their belongings at dawn, and depart; but of course they returned, for they dared not show their faces to Lewanika, and were afraid to travel alone. Finally they took up most of my things, and I made straight for Nyakatoro, arriving soaked through one evening two days after at a Mambari encampment, rubber loads made up, ready to start next day for the west. They fled into the rain, but returned, offered me presents, and we travelled in company. I saw many earthworms for the first time, and in a locality where the white ants were abundant, as proved by the anthills and the constant falling of branches of trees rotten through white ants and sudden with rain. Then I crossed the Luzabo, and later the Zambezi. I was most kindly treated by Messrs. Cunningham and Harford and their kind ladies at Kavungu, a mission station near Nyakatoro, founded by Mr. Arnot, who had travelled this country fifteen years ago. From here I rode a mission ox on to Kazombo, a day's journey down the Zambezi, where Dr. and Mrs. Fisher had recently started a new station. I found Major Gibbons had left about a month before. The first week was a sad one for the little English colony. Dr. Fisher received news of his father's death; Mr. Coppethorne, a fellow-helper, sickened and died, and a lady of the mission was down with fever. The doctor bad much to do, yet he took care of every little detail, the same care and attention being paid to the native sick. I would like to talk more of Dr. and Mrs. Fisher and his mission.

Travelling west with a caravan of Valovale-the most unlikable natives I have ever met-I passed through a flat country, jiggers especially favouring this low sandy soil. I met with many more here than when nearing the West Coast, but on entering the Vachibokwe country it became hilly and healthy. At the Portuguese stations of Kalunga, Kameia, and Mosico, the Portuguese officers were most. 
hospitable. As I passed west, ascending to country 6000 feet high, I stopped at several mission stations, everywhere receiving the greatest kindness. Then I descended into a tropical valley; and after crossing barren hills, Catumbella and the coast was reached. I arrived January 31, eighteen and a half months after leaving the mouth of the Zambezi. - I took up my abode in a Dutch house, until a messenger arrived from Benguella, 18 miles off, from Mr. Bullough, offering me a passage on his yacht to the Cape. There are many convalescent and wounded officers and men who have since known that yacht; they would understand my experience on boarding her. I shall never forget the kindness I received. I found my Zambezi boy seated in a deckchair, his loin-cloth discarded, and clothed in a suit of ducks, a yachtingcap on his head, and smoking a big cigar. Then I became sick, and I think Mr. Bullough and his friend, Mr. Mitchell, are responsible for my wearying you this evening.

Before the reading of the paper, the President said: We welcome here this evening once more our friend Major Gibbons, who read us a very interesting paper only a few years ago. He has now done, if possible, a still more important piece of work in the same region, and he has done it very thoroughly.

After the reading of the paper, the following discussion took place :-

Mr. E. G. Ravenstein : What we have heard to-night from Major Gibbons, and his companion, Captain Quicke, gives us a very imperfect notion of the very important work they have done. That will stand forth very prominently when their map is published ; for the map of the Marotse country, tracing their journeyings, is based on numerous observations for latitude, and very careful itinerary surveys, and will prove a valuable acquisition, and one that will stand the test of time. I think Major Gibbons was right to concentrate his energies upon one particular district; it is no use wasting time on flying visits to all sorts of peoples, but as he had no return ticket he did quite right in choosing a different route for leaving the country to that by which he had entered. And the route he chose is one of the most interesting; it took him along Lake Tanganyika, through the African "Interlaken," through Uganda and the Sudan to Egypt. Now about 'Tanganyika. Up till a few years ago, the lake was delineated in accordance with the map published by the R.G.S. in 1882. Well, at that time, so far as the south of the lake is concerned, we had one trustworthy longitude observed by a Belgian officer, Cambier, who left his theodolite at Karema, where it may be still. On that observation, and a rough triangulation made by Mr. Hore, and the more detailed information collected, and many latitudes, observed by men like Livingstone, Cameron, Joseph Thomson, and above all Stanley, the southern portion of the lake has been delineated, and has stood the test of time. In the delineation of the northern part of the lake we were still dependent upon fragmentary and unsatisfactory information. Mr. Fergusson has recently determined a number of longitudes, and he places the northern extremity 10 or 11 miles further west than the map of 1882. Dr. Baumann, who observed a longitude close by, shifted it 3 miles; but far greater differences exist in the middle of the lake in relation to its eastern and western coasts. Ujiji, according to different observers, varies $31^{\prime}$ in longitude, and Plymouth Rock, the missionary station on the western side of the lake, varies 